\title{
PENGARUH KEMAMPUAN VERBAL DAN PENYESUAIAN DIRI TERHADAP PRESTASI BELAJAR MATEMATIKA SISWA
}

\section{THE EFFECT OF VERBAL ABILITY AND SELF-ADJUSTMENT ON STUDENTS' MATHEMATICS ACHIEVEMENT}

\author{
Miranda Utama1), Tri Hariyati Nur Indah Sari'2), Nur Ismiyati ${ }^{3)}$ \\ 1,2,3)Universitas Balikpapan \\ mirandautama236@gmail.com ${ }^{11}$, tri.hariyati.nis@uniba-bpn.ac.id²), nurismiyati@uniba-bpn.ac.id3)
}

\begin{abstract}
Abstrak
Penelitian ini bertujuan untuk mengetahui apakah terdapat pengaruh kemampuan verbal, penyesuaian diri, serta kemampuan verbal dan penyesuaian diri secara bersama-sama terhadap prestasi belajar matematika siswa. Penelitian ini merupakan penelitian ex-post facto menggunakan pendekatan kuantitatif. Populasi berasal dari 180 siswa kelas XI IPA SMA Negeri 8 Balikpapan. Penelitian ini menggunakan rumus Slovin dan mendapatkan 125 siswa yang terlibat sebagai sampel penelitian. Instrumen penelitian ini menggunakan tes dan angket. Data hasil penelitian dianalisis menggunakan regresi linear sederhana dan berganda. Hasil uji t menunjukkan bahwa nilai signifikansi sebesar 0,000 (Sig. < 0,05), sehingga dapat disimpulkan bahwa terdapat pengaruh kemampuan verbal terhadap prestasi belajar matematika siswa. Selanjutnya, hasil uji t menunjukkan bahwa nilai signifikansi sebesar 0,297 (Sig. > 0,05), sehingga dapat disimpulkan bahwa tidak terdapat pengaruh penyesuaian diri terhadap prestasi belajar matematika siswa. Kemudian, hasil uji F menunjukkan bahwa nilai signifikansi sebesar 0,000 (Sig. < 0,05), sehingga dapat disimpulkan bahwa terdapat pengaruh kemampuan verbal dan penyesuaian diri secara bersama-sama terhadap prestasi belajar matematika siswa. Selain itu, faktor kondisi seperti perubahan kebiasaan siswa yang awalnya belajar secara tatap muka di sekolah berubah menjadi pembelajaran secara online dapat mempengaruhi pencapaian prestasi belajar matematika siswa karena membutuhkan kesiapan dan penyesuaian diri yang matang pada siswa maupun pendidik.
\end{abstract}

Kata Kunci: kemampuan verbal, penyesuaian diri, prestasi belajar matematika

\begin{abstract}
The research aims to know the effect of verbal ability, self-adjustment, verbal ability and selfadjustment simultaneously toward student's mathematic achievement. This research is expost facto research using a quantitative approach. The population came from 180 students of XI grade science class SMA Negeri 8 Balikpapan. This research used the Slovin formula and obtained 125 students involved a sample. This research used test and questionnaire as the instrument in this research. The data were analyzed using simple and multiple regression. The t-test result showed a significance value of 0,000 (Sig. < 0,05), so it could be concluded that there was an effect of verbal ability on students' mathematic achievement. Next, the $t$ test result showed a significance value of 0,297 (Sig. > 0,05), so it could be concluded that there was no effect of self-adjustment on students' mathematic achievement. Then, the F-test result showed a significance value of 0,000 (Sig. <0,05), so it could be concluded that there was an effect of verbal ability and self-adjustment simultaneously on students' mathematic achievement. Other than that, the condition factors such as changes in the habits of students who initially learn face-to-face at school turning into online learning can affect student achievement in mathematics learning because it requires mature readiness and adjustment in students and educators.
\end{abstract}


Keywords: verbal ability, self-adjustment, students' mathematics achievement

How to Cite: Utama, M., Sari, T. H. N. I., \& Ismiyati, N. (2020). Pengaruh kemampuan verbal dan penyesuaian diri terhadap prestasi belajar matematika siswa. Al asma: Journal of Islamic Education, 2(2), 160-169.

\section{PENDAHULUAN}

Perkembangan ilmu pengetahuan dan teknologi yang semakin pesat tentu dipengaruhi oleh kualitas pendidikan. Pendidikan merupakan wahana untuk meningkatkan dan mengembangkan kualitas sumber daya manusia. Dunia pendidikan yang terus maju, menuntut para lembaga pendidikan untuk bekerja lebih giat dalam meningkatkan prestasi siswa. Kegiatan proses pembelajaran merupakan kegiatan inti dalam upaya meningkatkan kualitas pendidikan. Oleh karena itu, baik dan buruknya suatu proses pembelajaran merupakan salah satu faktor yang paling banyak dalam menentukan kualitas pendidikan.

Berhasil atau tidaknya untuk meningkatkan prestasi belajar siswa tergantung oleh proses pembelajaran yang dilaksanakan. Keberhasilan yang dicapai dalam proses pembelajaran tidak hanya dilihat dari hasil akhir yang diraih siswa, namun banyak faktor yang mempengaruhi proses pembelajaran (Astuti, Susilo, \& Sari, 2018). Faktor-faktor tersebut biasanya terjadi saat proses pembelajaran berlangsung. Salah satu faktor yang mendukung dalam proses pembelajaran adalah kemampuan verbal yang dimiliki oleh siswa. Lestari (2019) menyatakan bahwa kemampuan verbal merupakan salah satu aspek yang dimiliki siswa sebagai potensi yang turut mempengaruhi prestasi belajar siswa. Kemampuan verbal sangat dibutuhkan oleh siswa dalam kegiatan pembelajaran. Hal tersebut dikarenakan kemampuan verbal memiliki peran untuk memahami bacaan terkait soal atau permasalahan matematika.

Menurut Nahak, Amsikan, \& Binsasi (2019), kemampuan verbal merupakan kemampuan untuk memahami hubungan kata, kosakata serta menerima dengan cepat kata-kata tertentu termasuk kemampuan mengingat kata-kata dan pola membentuknya. Kemampuan verbal juga membantu siswa dalam pemahaman kata dan kosakata, sehingga siswa dapat memahami serta mengkomunikasikan dan meyelesaikan masalah-masalah yang berkaitan dengan matematika. Oleh karena itu, siswa harus memiliki kemampuan verbal yang baik agar prestasi belajar juga mendapatkan hasil yang baik. Hal ini sejalan dengan Daniyati \& Sugiman (2015) apabila kemampuan verbal siswa kurang baik, maka siswa akan sulit dalam menyelesaikan soal matematika sehingga akan berdampak pada prestasi belajarnya.

Faktor lain yang dapat mempengaruhi kegiatan pembelajaran yaitu penyesuaian diri. Dalam proses pembelajaran, selain memerlukan kemampuan verbal terhadap materi pelajaran yang dipelajari juga diperlukan penyesuaian diri yang baik terhadap kondisi pembelajaran. Fatimah (Parerungan, 2018) menyatakan bahwa penyesuaian diri merupakan kemampuan individu untuk menerima dirinya sendiri sehingga tercapai hubungan yang harmonis antara dirinya dan lingkungannya. Penyesuaian diri yang baik akan membuat siswa merasa nyaman pada saat belajar. Hal ini sejalan dengan pendapat Achenbach (Damayanti, 2015) bahwa kemampuan anak dalam menyesuaikan diri dalam lingkungannya akan membuat anak merasa nyaman dan prestasi belajar dapat berhasil di sekolah. Tentunya faktor-faktor tersebut tak lepas dari peran guru pada saat pembelajaran 
dalam kelas. Guru harus dapat memilih strategi yang baik agar dapat mengaktifkan siswa dalam proses pembelajaran agar terjadi perubahan pada masing-masing diri siswa (Ismiyati, 2019).

Berdasarkan observasi di kelas XI IPA 2 dan XI IPA 4 SMA Negeri 8 Balikpapan dan wawancara kepada salah satu guru matematika kelas XI IPA, diperoleh bahwa siswa masih menganggap pelajaran matematika adalah pelajaran yang paling banyak ditakuti karena dianggap sulit. Siswa juga mengalami kesulitan ketika menyelesaikan soal yang diberikan secara individu. Ketika siswa mengalami kesulitan tersebut, mereka mencari siswa lain untuk membantu mereka menyelesaikan soal atau mencoba mencari jawaban melalui buku atau internet yang sama dengan masalah pada soal yang diberikan. Hal ini berdampak pada prestasi belajar matematika yang diperoleh siswa kurang maksimal. Hal tersebut terbukti pada perolehan nilai murni semester sebelumnya masih banyak yang di bawah nilai KKM dan ketika guru memberikan latihan soal pada saat pembelajaran siswa masih kesulitan untuk menyelesaikan soal di depan kelas. Hal tersebut juga disebabkan karena kemampuan untuk memahami bahasa serta kosakata dalam soal khususnya soal cerita masih lemah.

Hasil observasi juga terdapat faktor lain yang menjadi penyebab rendahnya prestasi belajar siswa yakni penyesuaian diri terhadap proses pembelajaran, terlihat dari kondisi pada saat pembelajaran berlangsung baik dari segi sosial dan kemampuan menjawab soal yang dimiliki masing-masing siswa. Terlihat bahwa siswa yang berani maju ke depan untuk menjawab soal-soal yang diberikan adalah siswa yang pandai saja serta masih banyak siswa yang kurang menjalin komunikasi antar siswa lainnya dalam kelas untuk berdiskusi tentang soal yang diberikan oleh guru.

Mengingat kondisi saat ini, segala bentuk pembelajaran di sekolah dilakukan secara online di rumah masing-masing siswa. Hal ini juga berdampak pada penyesuaian diri siswa berubah yang awalnya pembelajaran dilakukan secara tatap muka kemudian beralih ke pembelajaran secara online. Terdapat siswa yang mampu menyesuaikan diri untuk belajar secara online dan ada juga siswa yang kurang mampu menyesuaikan diri pada kondisi belajar secara online. Siswa dituntut untuk berusaha menyesuaikan dirinya mulai dari persiapan pembelajaran, sarana untuk belajar secara online dan persiapan lainnya demi menunjang pembelajaran online terlaksana secara maksimal. Dengan demikian, kemampuan verbal dan penyesuaian diri pada masing-masing siswa sangat perlu diperhatikan agar prestasi belajar matematika siswa dapat meningkat walaupun di tengah kondisi pandemi saat ini. Terutama penyesuaian diri siswa yang sangat berkaitan dengan penyesuaian pada saat belajar di sekolah dengan pembelajaran online di rumah masing-masing siswa. Oleh karena itu, perlu dikaji lebih dalam mengenai kemampuan verbal dan penyesuaian diri siswa pada saat kondisi seperti ini berpengaruh atau tidak terhadap prestasi belajar matematika siswa.

Penelitian yang dilakukan oleh Malmia \& Papalia (2019) menyatakan bahwa kemampuan verbal dan penyesuaian diri secara bersama-sama memiliki pengaruh yang sangat signifikan terhadap prestasi belajar matematika siswa. Dengan perolehan koefisien determinasi sebesar 56,1\%. Kemudian penelitian yang dilakukan oleh Daniyati \& Sugiman (2015) yang menyimpulkan bahwa terdapat hubungan yang signifikan antara kemampuan verbal dengan prestasi belajar matematika siswa SMP. Dengan perolehan kontribusi kemampuan verbal terhadap prestasi belajar matematika sebesar $23,62 \%$. Selanjutnya 
penelitian oleh Costa, Hanurawan, Atmoko, \& Hitipeuw (2018) menyimpulkan bahwa if self-adjustment of the Timorese student was implementing well, it will elevate and increase their academic achievement. Artinya jika penyesuaian diri siswa Timor-Leste baik, maka akan berpengaruh dan meningkatnya prestasi akademik siswa. Diperoleh bahwa kontribusi penyesuaian diri terhadap prestasi akademik sebesar 46,1\%. Berdasarkan penelitian relevan maka dapat disimpulkan bahwa kemampuan verbal dan penyesuaian diri memiliki peran penting dalam meningkatkan prestasi belajar matematika. Oleh karena itu, peneliti tertarik untuk melakukan penelitian yang berjudul "Pengaruh Kemampuan Verbal dan Penyesuaian Diri terhadap Prestasi Belajar Matematika Siswa”.

\section{METODE PENELITIAN}

Penelitian ini menggunakan pendekatan kuantitatif dengan jenis penelitian Ex-post Facto. Penelitian ini dilakukan di kelas XI IPA SMA Negeri 8 Balikpapan dengan jumlah populasi 180 siswa. Sampel yang digunakan sebanyak 125 siswa yang diperoleh menggunakan rumus Slovin. Pengambilan sampel menggunakan teknik proportionate stratified random sampling. Perhitungan sampel menggunakan rumus Slovin yang dijabarkan oleh Sujarweni dan Endrayanto (Tania, Hadiwinarto, \& Sinthia, 2018) sebagai berikut:

$$
n=\frac{N}{1+N e^{2}}=\frac{180}{1+180(0,05)^{2}}=\frac{180}{1,45}=124,135 \approx 125
$$

Keterangan:

$n \quad=$ jumlah sampel minimal

$N \quad=$ jumlah populasi

$E \quad=$ taraf kesalahan $(5 \% / 0,05)$

Desain penelitian yang digunakan merujuk pada Sardia \& Saharuddin (2017) sebagai berikut:

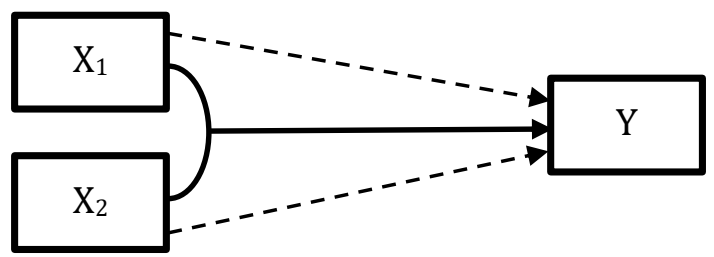

Gambar 1. Desain Penelitian

Keterangan:

$\mathrm{X}_{1} \quad$ : Variabel bebas 1 (kemampuan verbal)

$\mathrm{X}_{2} \quad$ : Variabel bebas 2 (penyesuaian diri)

Y $\quad$ : Variabel terikat (prestasi belajar matematika)

Instrumen pengumpulan data menggunakan tes kemampuan verbal dan angket penyesuaian diri siswa. Adapun indikator untuk tes kemampuan verbal adalah (1)perbendaharaan kata, (2)simbol, (3)persamaan kata, (4)lawan kata. Indikator untuk angket penyesuaian diri yaitu (1)penyesuaian akademik, (2)penyesuaian sosial, (3)penyesuaian emosi pribadi, (4)penyesuaian institusi. Pengambilan data dilakukan secara online dengan tes menggunakan website Quizizz dan angket menggunakan Google Form. Data dalam penelitian ini menggunakan analisis statistik deskriptif dan analisis 
statistik inferensial. Analisis deskriptif meliputi pengkategorian persentase maksimal dan minimal pada indikator kemampuan verbal dan penyesuaian diri. Analisis statistik inferensial meliputi uji prasyarat dan uji hipotesis. Uji prasyarat meliputi uji normalitas, heteroskedastisitas, linearitas, dan mutikolinearitas. Untuk uji hipotesis menggunakan analisis regresi sederhana dan berganda. Data dianalisis menggunakan aplikasi SPSS for Windows. Kemudian, untuk kriteria pencapaian indikator tes kemampuan verbal dan angket penyesuaian diri dijabarkan oleh Riduwan dalam Luzyawati (2017) pada tabel 1.

Tabel 1. Kriteria Persentase Pencapaian Persentase Indikator

\begin{tabular}{ccc}
\hline No. & Persentase & Kriteria/aspek kualitas \\
\hline 1 & $81-100$ & Sangat Baik \\
2 & $61-80$ & Baik \\
3 & $41-60$ & Sedang \\
4 & $21-40$ & Buruk \\
5 & $0-20$ & Sangat Buruk \\
\hline
\end{tabular}

\section{HASIL DAN PEMBAHASAN}

Analisis deskriptif meliputi persentase maksimal dan minimal pada tes kemampuan verbal dan angket penyesuaian diri siswa. Pada tes kemampuan verbal diketahui bahwa persentase indikator maksimal diperoleh pada indikator simbol sebesar 89,06\%. Untuk persentase indikator minimal diperoleh pada indikator perbendaharaan kata sebesar 78,31\%. Sedangkan untuk angket penyesuaian diri diketahui bahwa persentase indikator maksimal diperoleh pada indikator institusi sebesar 77,14\%. Untuk persentase indikator minimal diperoleh pada indikator penyesuaian akademik sebesar $67,44 \%$.

Analisis regresi menggunakan uji t yang bertujuan untuk mengetahui apakah terdapat pengaruh kemampuan verbal dan penyesuaian diri secara parsial terhadap prestasi belajar matematika. Berikut ini tabel hasil uji t:

Tabel 2. Hasil Uji t

\begin{tabular}{ccc}
\hline Variabel & $\boldsymbol{t}$ & Signifikansi (Sig.) \\
\hline $\begin{array}{c}\text { Kemampuan verbal terhadap prestasi belajar } \\
\text { matematika }\end{array}$ & 6,039 & 0,000 \\
$\begin{array}{c}\text { Penyesuaian diri terhadap prestasi belajar } \\
\text { matematika }\end{array}$ & $-1,048$ & 0,297 \\
\hline
\end{tabular}

Berdasarkan tabel 2 diperoleh bahwa terdapat pengaruh kemampuan verbal terhadap prestasi belajar matematika siswa kelas XI IPA SMA Negeri 8 Balikpapan. Hal ini dapat dilihat dari hasil analisis persamaan regresi ganda bahwa nilai koefisien regresi untuk kemampuan verbal bernilai positif. Hal ini artinya terdapat hubungan yang positif antara kemampuan verbal dengan prestasi belajar matematika, semakin naik kemampuan verbal semakin meningkat prestasi belajar matematika siswa. Pada pengujian hipotesis juga diperoleh bahwa nilai $t_{\text {hitung }}$ adalah 6,039 dengan nilai signifikansi sebesar 0,000 yang menunjukkan bahwa nilai signifikansi kurang dari 0,05.

Oleh karena itu, semakin tinggi kemampuan verbal yang dimiliki siswa maka akan semakin tinggi juga prestasi belajar siswa. Hal tersebut sejalan dengan Awofala, Balogun \& 
Olagunju (Daniyati \& Sugiman, 2015) yang menyatakan bahwa siswa dengan kemampuan verbal yang baik menunjukkan prestasi belajar yang lebih baik dibandingkan siswa dengan kemampuan verbal yang kurang baik. Hal ini karena kemampuan verbal dapat melatih siswa untuk memahami ide dan kosakata dalam soal. Soeharno (Wahyudin, 2016) yang menyatakan bahwa dengan kemampuan verbal yang tinggi, seseorang dapat memahami ide serta konsep dan juga dapat dengan mudah berpikir serta memecahkan masalah yang dinyatakan dalam bentuk kata-kata. Nahak et al. (2019) menambahkan bahwa kemampuan verbal membantu siswa untuk memahami kosakata, hubungan kata, sehingga siswa dapat memahami serta mengkomunikasikan dan menyelesaikan permasalahan matematika.

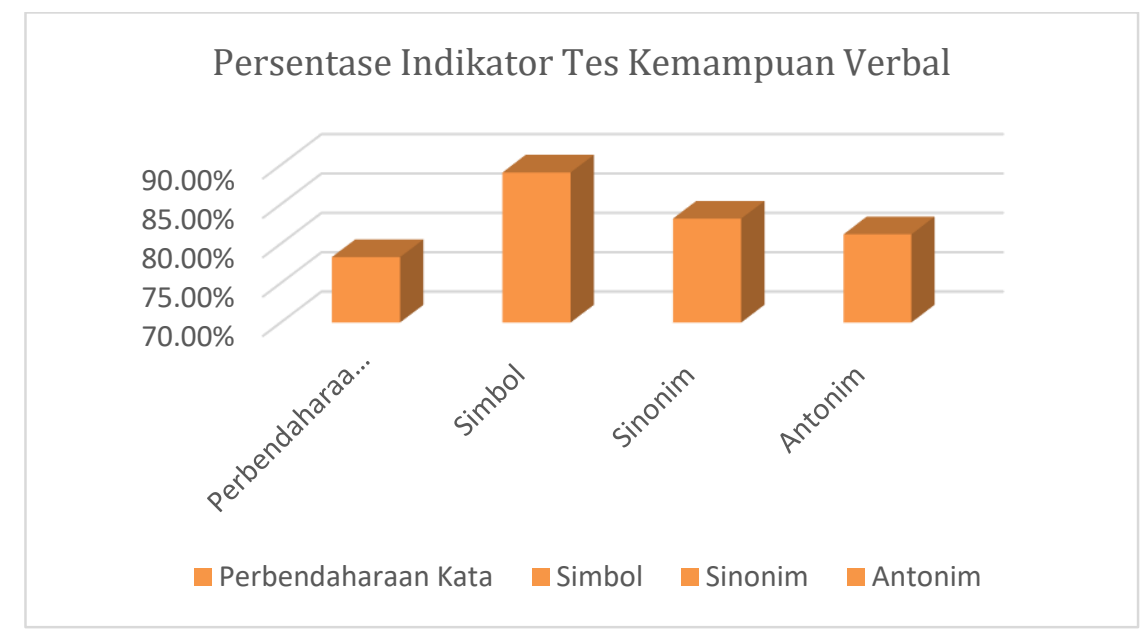

Gambar 2. Grafik Persentase Indikator Tes Kemampuan Verbal

Berdasarkan gambar 2 diperoleh bahwa indikator kemampuan verbal dengan persentase tertinggi adalah indikator simbol dengan perolehan persentase sebesar 89,06\%. Persentase tersebut masuk dalam kategori sangat baik. Yunarni, Awi, \& Asdar, (2015) menyatakan bahwa penggunaan simbol-simbol matematika secara tepat akan membuat siswa mudah mengkomunikasikan masalah dalam soal secara efisien dengan bahasa matematika. Oleh karenanya, jika terjadi kesalahan penulisan simbol, hal tersebut akan mengganggu siswa untuk mempelajari matematika lebih lanjut. Sejalan dengan penelitian Nurhatianti \& Karlimah, (2018) yang menyatakan bahwa indikator kemampuan memahami simbol dalam permasalahan matematika berada pada kategori tinggi dengan persentase sebesar $96,87 \%$.

Berdasarkan tabel 2 diperoleh bahwa tidak terdapat pengaruh penyesuaian diri terhadap prestasi belajar matematika siswa kelas XI IPA SMA Negeri 8 Balikpapan. Hal ini dapat dilihat pada hasil analisis persamaan regresi ganda bahwa koefisien untuk penyesuaian diri bernilai negatif. Hal ini berarti terdapat hubungan negatif antara penyesuaian diri dengan prestasi belajar matematika, semakin naik penyesuaian diri maka semakin turun prestasi belajar matematika. Pada pengujian hipotesis juga diperoleh bahwa nilai $t_{\text {hitung }}$ adalah $-1,048$ dan nilai signifikansi sebesar 0,297 yang berarti bahwa nilai signifikansi lebih dari 0,05 .

Hal tersebut tidak sesuai dengan teori-teori yang menyatakan bahwa penyesuaian diri berpengaruh terhadap prestasi belajar matematika siswa. Seperti yang dikemukakan 
oleh Arifin et al. (2016) yang penelitiannya dikatakan bahwa penyesuaian diri memiliki hubungan yang positif dan signifikan terhadap prestasi akademik. Sejalan dengan pendapat Tallent (Lidya \& Darmayanti, 2015) yang menyatakan bahwa penyesuaian diri memiliki pengaruh dalam peningkatan prestasi belajar. Inayati \& Savira (2017) menambahkan bahwa siswa yang memiliki penyesuaian diri yang baik akan berusaha mencari solusi untuk mengatasi kesulitan dalam belajar baik dengan cara membuat strategi penyelesaian masalah, bertanya kepada teman dan guru atau menemukan solusi lainnya untuk memperoleh prestasi belajar yang baik.

Sebaliknya, hasil penelitian ini sesuai dengan penelitian yang dilakukan oleh Damayanti (2015) tentang peran belajar berdasarkan regulasi diri dan penyesuaian diri terhadap prestasi belajar. Penelitiannya terhadap 121 siswi kelas satu pada salah satu madrasah dengan alat ukur penelitian angket serta prestasi belajar menggunakan nilai rapor. Hasil temuannya menyatakan bahwa penyesuaian diri tidak mempunyai peran yang signifikan terhadap prestasi belajar yang ditunjukkan pada nilai signifikansinya sebesar 0,072. Sardia \& Saharuddin (2017) juga melakukan penelitian berjudul pengaruh kemampuan verbal dan penyesuaian diri terhadap prestasi belajar fisika siswa berkepribadian sanguinis dan koleris. Penelitian yang dilakukan pada siswa SMA Negeri 1 Baraka dengan alat ukur penelitian berupa tes kepribadian, tes kemampuan verbal, dan tes penyesuaian diri serta prestasi belajar mengunakan nilai rapor. Hasil yang ditemukan bahwa tidak terdapat pengaruh penyesuaian diri terhadap prestasi belajar fisika pada siswa berkepribadian sanguinis.

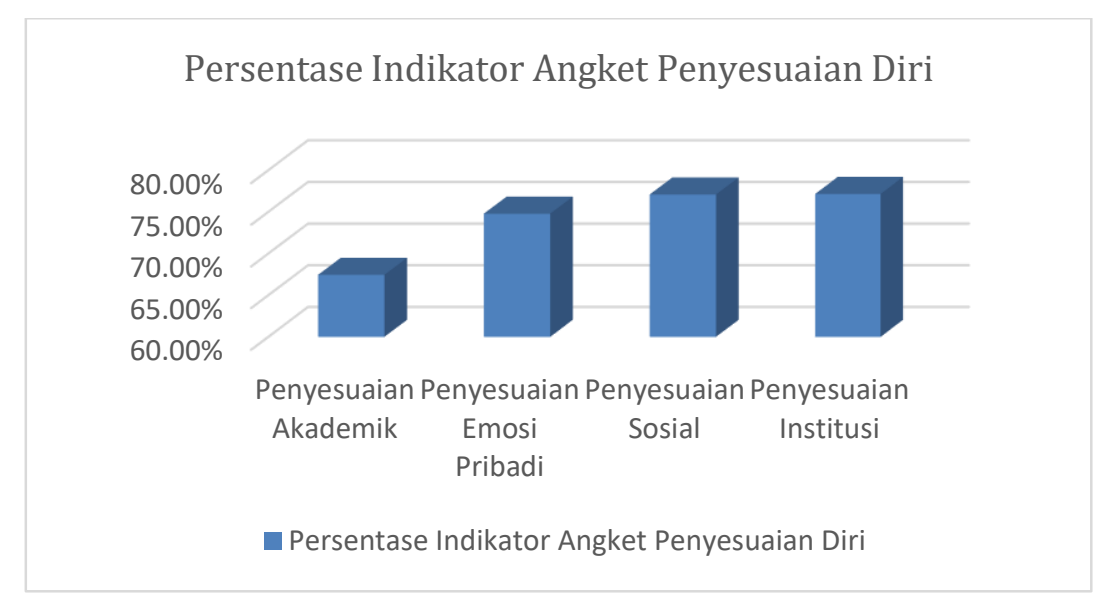

Gambar 3. Grafik Persentase Indikator Angket Penyesuaian Diri

Berdasarkan gambar 3 diperoleh bahwa indikator dengan persentase terendah yaitu penyesuaian akademik sebesar 67,44\% dengan kategori baik. Desmita (Kasari \& Sawitri, 2018) menyatakan bahwa seseorang yang kurang dalam penyesuaian diri dengan lingkungannya akan menunjukkan reaksi yang tidak efisien serta tidak memuaskan. Meskipun indikator pada penyesuaian akademik masuk dalam kategori baik, namun beberapa siswa masih menunjukkan respon yang kurang maksimal. Seperti pernyataan pada indikator penyesuaian akademik dengan skor terendah sebesar 383 yaitu saya kurang puas dengan situasi akademis saya di sekolah. Hal tersebut bisa saja dipengaruhi oleh kurang maksimal pembelajaran yang telah dilaksanakan di dalam kelas sehingga menyebabkan perolehan hasil akademis siswa juga kurang memuaskan. Hal tersebut 
sejalan dengan Sari, (2016) yang menyatakan bahwa upaya untuk mengembangkan kemampuan siswa terutama dalam matematika adalah dengan merancang suatu pembelajaran yang akan dilaksanakan di kelas dengan tepat.

Kemudian selain faktor penyebab di atas, penyesuaian diri siswa yang mulanya belajar secara tatap muka di sekolah berubah menjadi pembelajaran secara online di rumah masing-masing dikarenakan kondisi pandemi COVID-19 saat ini. Hal ini juga berdampak pada penyesuaian diri siswa untuk menyesuaikan kondisi pembelajaran serta fasilitas demi menunjang pembelajaran online agar lebih baik. Hal tersebut sejalan dengan Purwanto et al., (2020) yang menyatakan bahwa pelajar, siswa, dan mahasiswa mendapatkan dampak negatif karena "dipaksa" belajar dari rumah dikarenakan pembelajaran secara tatap muka ditiadakan akibat pandemi COVID-19 saat ini. Padahal tidak semua pelajar, siswa dan mahasiswa siap dan terbiasa belajar secara online.

Analisis regresi selanjutnya menggunakan uji $\mathrm{F}$ yang bertujuan untuk mengetahui apakah terdapat pengaruh atau tidak secara simultan atau bersama-sama. Dalam pengujiannya taraf signifikansi yang digunakan adalah $\alpha=5 \%$ atau $\alpha=0,05$. Berikut ini merupakan tabel hasil uji F:

Tabel 3. Hasil Uji F

\begin{tabular}{ccc}
\hline Model & F & Signifikansi (Sig.) \\
\hline Regresi & 18,326 & 0,000 \\
\hline
\end{tabular}

Berdasarkan tabel 3 diperoleh bahwa terdapat pengaruh kemampuan verbal dan penyesuaian diri secara bersama-sama terhadap prestasi belajar. Diketahui bahwa nilai signifikansi pada uji $\mathrm{F}$ adalah 0,000 dimana nilai signifikansi tersebut kurang dari 0,05 dengan nilai $F_{\text {hitung }}$ sebesar 18,326. Sehingga dari hasil uji $\mathrm{F}$ dapat disimpulkan bahwa terdapat pengaruh antara kemampuan verbal dan penyesuaian diri secara bersama-sama terhadap prestasi belajar matematika siswa kelas XI IPA SMA Negeri 8 Balikpapan. Persamaan regresi pada penelitian ini adalah:

$$
Y=52,032+0,455 X_{1}-0,067 X_{2}
$$

Hasil penelitian ini sejalan dengan Rustam (2015) yang menyatakan bahwa terdapat pengaruh yang positif dan signifikan antara kemampuan verbal dan penyesuaian diri terhadap prestasi belajar matematika. Hal tersebut sejalan dengan Malmia \& Papalia (2019) yang menyatakan bahwa semakin baik kemampuan verbal dan penyesuaian diri yang dimiliki siswa, maka prestasi belajar matematika siswa semakin baik juga. Sardia \& Saharuddin (2017) juga menambahkan bahwa jika kemampuan verbal dan penyesuaian diri secara bersama-sama ditanamkan secara optimal maka akan memberikan dampak positif bagi prestasi belajar.

Penelitian ini memiliki beberapa perbedaan dengan penelitian terdahulu. Pada penelitian ini pengambilan data dilakukan secara online dengan menggunakan Quizizz untuk tes dan Google Form untuk angket. Hal ini disebabkan karena kondisi pandemi saat ini yang mengharuskan pertemuan secara langsung diminimalkan. Penelitian ini menggunakan indikator-indikator yang dikembangkan dan disesuaikan dengan kondisi saat ini. Seperti pada angket penyesuaian diri yang butir-butir pernyataannya dikembangkan dengan menyesuaiakan kondisi siswa dengan pandemi COVID-19 dan pada 
kenyataannya faktor kondisi seperti perubahan kebiasaan siswa yang awalnya belajar secara tatap muka di sekolah berubah menjadi pembelajaran secara online dapat mempengaruhi pencapaian prestasi belajar matematika siswa karena membutuhkan kesiapan dan penyesuaian diri yang matang pada siswa maupun pendidik.

\section{SIMPULAN}

Berdasarkan hasil penelitian dan pembahasan, maka dapat disimpulkan bahwa kemampuan verbal dan penyesuaian diri memiliki kontribusi yang baik terhadap prestasi belajar matematika. Semakin tinggi kemampuan verbal dan penyesuaian diri siswa, maka akan semakin tinggi pula prestasi belajar matematika siswa. Namun secara parsial kemampuan verbal memiliki pengaruh yang besar terhadap peningkatan prestasi belajar matematika sedangkan untuk penyesuaian diri kurang berpengaruh terhadap peningkatan prestasi belajar matematika siswa.

\section{DAFTAR PUSTAKA}

Arifin, M., Dardiri, A., \& Handayani, A. N. (2016). Hubungan kemampuan penyesuaian diri dan pola berpikir dengan kemandirian belajar serta dampaknya pada prestasi akademik mahasiswa. Jurnal Pendidikan: Teori, Penelitian, dan Pengembangan, 1(10), 1943-1951.

Astuti, D., Susilo, G., \& Sari, T. H. N. I. (2018). Pengaruh konsentrasi belajar dan kemandirian belajar terhadap hasil belajar matematika siswa kelas XI SMA Negeri 2 Balikpapan Tahun Ajaran 2017/2018. De Fermat: Jurnal Pendidikan Matematika, 1(2), 42-53. https://doi.org/10.36277/defermat.v1i2.25.

Costa, A., Hanurawan, F., Atmoko, A., \& Hitipeuw, I. (2018). The impact of self-adjustment on academic achievement of the students. ISLLAC, 2(1), 1-6.

Damayanti, E. (2015). Peran belajar berdasarkan regulasi diri dan penyesuaian diri terhadap prestasi belajar siswi madrasah tsanawiyah muallimat yogyakarta. Jurnal Biotek, 3(2), 54-69.

Daniyati, N. A., \& Sugiman. (2015). Hubungan antara kemampuan verbal, kemampuan interpersonal, dan minat belajar dengan prestasi belajar matematika. PYTHAGORAS: Jurnal Pendidikan Matematika, 10(1), 50-60.

Inayati, Z. F., \& Savira, S. I. (2017). Hubungan antara penyesuaian diri dan regulasi emosi dengan prestasi belajar matematika pada siswa kelas VIII SMP Hang Tuah 4 Surabaya. Jurnal Psikologi Pendidikan, 4(1), 1-6.

Ismiyati, N. (2019). Penerapan model pembelajaran ARIAS (Assurance, Relevance, Interest, Assessment, and Satisfaction) untuk meningkatkan aktivitas dan hasil belajar siswa. De Fermat: Jurnal Pendidikan Matematika, 2(1), 28-38. https://doi.org/10.36277/defermat.v2i1.35.

Kasari, W., \& Sawitri, D. R. (2018). Hubungan antara penyesuaian diri dengan motivasi belajar pada siswa kelas X di SMA Negeri 8 Purwokerto. Empati, 7(Nomor 1), 368372.

Lestari, N. A. P. (2019). Pengaruh implementasi pembelajaran kontekstual terhadap hasil belajar matemtika dengan kovariabel kemampuan numerik dan kemampuan verbal. Jurnal Pendidikan Dasar Nusantara, 5(1), 72-87.

Lidya, S. F., \& Darmayanti, N. (2015). Self-efficacy akademik dan penyesuaian diri siswa Kelas X SMA Patra Nusa. DIVERSITA, 1(1), 43-55. 
Luzyawati, L. (2017). Analisis kemampuan berpikir kritis siswa SMA materi alat indera melalui model pembelajaran inquiry pictorial riddle. EduSains, 5(2), 9-21.

Malmia, W., \& Papalia, I. (2019). Pengaruh kemampuan verbal dan penyesuaian diri terhadap prestasi belajar matematika siswa kelas VIII SMP 12 Buru. Jurnal JP3, 9(1), 724-732.

Nahak, Y. L., Amsikan, S., \& Binsasi, E. (2019). Pengaruh kemampuan verbal dan kemampuan numerik terhadap prestasi belajar matematika siswa SMPS Katolik Aurora Kefamenanu. Jurnal Saintek Lahan Kering, 2(1), 10-12.

Nurhatianti, R., \& Karlimah. (2018). Analisis kemampuan komunikasi matematis siswa Kelas II SD pada penyelesaian soal cerita perkalian bilangan pecahan. PEDADIDAKTIKA, 5(2), 119-128.

Parerungan, R. H. (2018). Kompetensi kerja dan penyesuaian diri pada fresh graduate fakultas keguruan dan ilmu pendidikan di universitas mulawarman yang tidak bekerja sebagai guru. Psikoborneo, 6(4), 846-856.

Purwanto, A., Pramono, R., Asbari, M., Santoso, P. B., Wijayanti, L. M., Hyun, C. C., \& Putri, R. S. (2020). Studi eksploratif dampak pandemi COVID-19 terhadap Proses pembelajaran online di sekolah dasar. EduPsyCouns, 2(1), 2716-4446.

Rustam. (2015). Hubungan kemampuan verbal dan penyesuaian diri terhadap prestasi belajar matematika siswa sekolah menengah pertama. Jurnal Pendidikan Matematika Dan Sains, 22(1).

Sardia, \& Saharuddin, A. (2017). Pengaruh kemampuan verbal dan penyesuaian diri terhadap prestasi belajar fisika siswa berkepribadan sanguinis dan koleris di SMA N 1 Baraka. Jurnal Edumaspul, 1(1), 9-14.

Sari, T. H. N. I. (2016). Pengaruh model pembelajaran Missouri Mathematics Project (MMP) terhadap kemampuan pembuktian matematis siswa SMP. Matematika Jurnal, 3(2), 22-35.

Tania, L. R., Hadiwinarto, \& Sinthia, R. (2018). Hubungan antara kecerdasan emosi dengan perilaku penyesuaian diri yang salah pada Siswa SMP Negeri 6 Kota Bengkulu. ONSILIA, 1(3), 79-90.

Wahyudin. (2016). Analisis kemampuan menyelesaikan soal cerita matematika ditinjau dari kemampuan verbal. BETA: Jurnal Tadris Matematika, 9(2), 148-160.

Yunarni, A., Awi, D., \& Asdar. (2015). Profil pemahaman notasi aljabar ditinjau dari kemampuan verbal siswa di kelas V Sekolah Dasar. DAYA MATEMATIS, 3(1), 1-9. 